\title{
PENGARUH PEMBERIAN TOPIKAL EKSTRAK KOLAGEN KULIT IKAN LELE SANGKURIANG (CLARIAS GARIEPINUS VAR) TERHADAP TNF-A DAN JUMLAH FIBROBLAST PADA LUKA BAKAR DERAJAT DUA TIKUS WISTAR
}

\author{
Aisyah $^{1}$, Zainatul Mufarikoh ${ }^{2}$, Ary Andini ${ }^{3}$ \\ ${ }^{1}$ Staf Pengajar Kedokteran Fisik dan Rehabilitasi Medik, Fakultas Kedokteran, Universitas Nahdlatul Ulama \\ Surabaya \\ ${ }^{2}$ Staf Pengajar Sistem Informasi, Fakultas Teknik, Universitas Nahdlatul Ulama Surabaya \\ ${ }^{3}$ Staf Pengajar Analis Kesehatan, Fakultas Kesehatan, Universitas Nahdlatul Ulama Surabaya \\ Email: aisyahdr@unusa.ac.id
}

\begin{abstract}
Background: Collagen has vital role on healing process of burn injuries, mainly in connective tissue. Collagen triggers fibroblast proliferation, support to form new granulation tissue and epithelium around wound. Wound treatment through collagen extract of Sangkuriang catfish skin can increase healing process. It stimulates humidity on level II burn injuries and encourage re-epithelization, proliferation and cell migration also increases growth. Methods: This is an experimental studies using 4 groups of Rattus Norvegicus (Wistar strain). All of the group get a burn injuries in their back skin. Control group 1 (K1) was treated by lidocaine for three days and control group 2 (K2) for ten days. Whereas treatment group 1 (P1) get lidocaine and collagen extract from Sangkuriang cat fish for 3 days and treatment group 2 (P2) for 10 days. Result: Number of fibroblast/field of view on treatment group showed significantly increased compared control groups on the 3 rd days $(\mathrm{P}=0,046)$ and the 10th $(\mathrm{P}=0,004)$. Percentage of TNF- $\alpha$ on level II-burn injuries in wistar rats showed significant difference. Percentage of TNF- $\alpha$ lower than treatment group and showed significant lowering level compared control groups on the10th $(\mathrm{P}=0,022)$. Conclusion: Increasing of firoblast number and lowering level of TNF- $\alpha$ significantly showed collagen extract of Sangkuriang cat fish skin accelerate wound healing process.
\end{abstract}

Keywords: Burn Injuries, Catfish, Collagen, Fibroblast, TNF- $\alpha$

\section{PENDAHULUAN}

Luka bakar merupakan salah satu masalah yang cukup serius bagi dunia kesehatan. Menurut Riset Kesehatan Dasar (Riskesdas), 2013 prevalensi cedera akibat luka bakar di Indonesia mencapai $70 \%$ pada tahun 2013. Pada luka bakar derajat2 (partial thickness burn) terjadi kerusakan pada seluruh epidermis dan sebagian dermis dengan indikasi terdapat bulla, sedikit oedem, serta nyeri berat. Pada proses penyembuhan luka terdapat empat fase yang terlibat yaitu fase haemostasis, inflamasi, fase proliferasi dan fase remodelin.

Pada fase inflamasi, monosit berdiferensiasi menjadi makrofag yang menginduksi aktivasi sitokin pro- inflamasi, yaitu Tumor Necrosis Factor- $\alpha$ (TNF- $\alpha)$. Pada fase proliferasi terjadi proliferasi fibroblast yang memicu penyusunan ekstra seluler matriks (ECM) dan keratinosit untuk reepitelisasi. Pemeriksaan TNF- $\alpha$ pada proses penyembuhan luka dapat diamati secara imunohistokimia dan jumlah fibroblast dapat diamati secara histopatologi.

Stress Oksidatif terjadi ketidakseimbangan antara anti-ROS antioksidan dengan radikal bebas [Reactive Oxygen Spesies (ROS)] yang berlebih di dalam tubuh. Jika terjadi stress oksidatif pada luka akan mengakibatkan intensitas proses oksidasi pada jaringan luka meningkat dan menimbulkan kerusakan yang lebih parah pada jaringan tersebut. Malondialdehide (MDA) sebagai produk katabolisme dari membrane fosfolipid yang menjadi pertanda adanya stress oksidatif. Konsentrasi MDA plasma lebih tinggi pada penderita luka bakar tertentu, seperti terjadi pada pasien luka bakar yang 
mengalami kerusakan jaringan yang cukup parah dan masa penyembuhan yang lama.

Dalam mempercepat proses penyembuhan luka dibutuhkan suasana lembab karena dapat meningkatkan re-epitelisasi dan menstimulasi proliferasi dan migrasi sel epitel, meningkatkan aktivitas growth factor yang memelihara oksigen permukaan yang cukup dan menjaga transport nutrisi (Hidayat, 2013). Oleh karena itu moiststate telah banyak diaplikasikan pada hidrogels dan pembalut luka (wound dressing) agar proses penyembuhan luka bisa berjalan optimal dan cepat. Salah satu bahan yang telah banyak digunakan untuk menjaga suasana lembap pada luka adalah kolagen. Kolagen berperan secara vital pada proses penyembuhan luka pada jaringan konektif. Makrofag pada luka melepaskan FGF dan TGF- $\beta$ sehingga merangsang proliferasi fibroblast dan menghasilkan kolagen (Gaspar, et al.,2012).

Kolagen kulit atau sisikikan lebih unggul jika dibandingkan dengan kolagen ternak dan unggas karena bebas dari Bovine Spongioform Encelopathy (BSE), Transmissible Spongioform Encephalopathy (TSE) dan Foot and Mouth Disease (FMD) (Singh et al.,2010) yang banyak menjangkit hewan ternak dan unggas. Selain itu,kolagen ikan halal untuk dikonsumsi dan mendukung dalam penyembuhan luka dengan resiko tingkat imunoreaktif yang rendah. Kolagen kulit atau sisikikan memiliki kandungan glisin yang relative tinggi untuk tetap menjaga suasana lembab pada kulit, dan kandungan hidroksi prolinyang relatif rendah sehingga menyebabkan kolagen ikan cenderung lebih elastic dibandingkan pada kolagen unggas dan hewan ternak. Pada penelitian ini digunakan sumber kolagen yang berasal dari kulit ikan Lele Sangkuriang (Clarias gariepinus var) yang menjadi limbah dari homeindustry pembuatan nugget dan kerupuk ikan Lele di kecamatan Tanggulangin, Sidoarjo. Dengan demikian pemanfaatan ekstrak topical kolagen kulit ikan Lele sebagai terapi penyembuhan luka akan memberikan sumbangsih pada perkembangan dan kemajuan obat di Indonesia berbasis eco-green.

\section{METODE PENELITIAN}

\section{Ekstraksi Kolagen Kulit Ikan Lele Sangkuriang}

Ekstraksi kolagen kulit Ikan lele Sangkuriang dilakukan dengan melakukan masrasi kulit ikan lele Sangkuriang sebanyak $500 \mathrm{~g}$ dalam $\mathrm{HCl} 2 \%$ selama 48 jam dengan perbandingan 1:8 (w/v) dan disimpan dalam lemari es. Filtrat (cairan hasil penyaringan) dipisahkan dengan residunya menggunakan kain penyaring sifon yang memiliki ukuran por $\mathrm{i} \pm 0,5 \mathrm{~mm}$. Kemudian filtrat dinetralisasi dengan menggunakan $\mathrm{NaOH} 1 \mathrm{M}$ pada $\mathrm{pH}$ netral sekitar 7. Saat mendekati $\mathrm{pH}$ netral, akan terlihat serat kolagen. Selanjutnya serat kolagen didiamkan selama 24 jam sehingga mengendap di dasar beakerglass. Akhirnya, kolagen disaring dengan menggunakan kain penyaring dengan ukuran pori $\pm 1 \mu \mathrm{m}$ sehingga didapatkan ekstrak kolagen kulit ikan lele Sangkuriang.

\section{PERLAKUAN KE HEWAN COBA}

Penelitian ini menggunakan tikus putih jantan (Rattus norvegicus) galur Wistar berusia sekitar 3 bulan yang sehat dan memiliki berat 200-250 gram. Dari jumlah sampel yang telah memenuhi syarat diambil secara alokasi random dan dibagi menjadi 2 kelompok, yaitu kelompok kontrol (K) dan kelompok perlakuan (P). Kelompok kontrol dibagi menjadi kelompok kontrol 1 (K1) dan kelompok kontrol2 (K2). Kelompok perlakuan dibagi menjadi kelompok perlakuan 1 (P1) dan kelompok perlakuan 2 (P2). Pada kelompok tikus kontrol 1 (K1), tikus dikenai luka bakar pada punggung dan dioleskan lidocain selama 3 hari dan kelompok tikus kontrol 2 (K2) selama 10 hari. Pada kelompok tikus Perlakuan 1 (P1), tikus dikenai luka bakar pada punggung dan dioleskan dengan lidocain selanjutnya dioleskan ekstrak kolagen kulit ikan Lele Sangkuriang selama 3 hari dan kelompok tikus perlakuan 2 (P2) selama 10 hari. 


\section{HASIL PENELITIAN}

\section{Analisis Jumlah Fibroblast}

Hasil analisis statistik jumlah fibroblast / lapangan pandang berdasarkan hasil uji Mann Whitney jumlah fibroblas hewan coba pada kelompok K1, P1, K2, dan P2 dirangkum pada tabel 2. Uji Mann Whitney dilakukan apabila membandingkan hanya 2 populasi yang berbeda.

Tabel 1. Hasil analisis jumlah fibroblast tikus Wistar

\begin{tabular}{ccc}
\hline Kelompok & Mean \pm Std & P-value \\
\hline K1 & $10,600 \pm 1,140$ & \\
\hline P1 & $12,400 \pm 2,408$ & 0,046 \\
\hline K2 & $20,800 \pm 1,923$ & \\
\hline P2 & $41,400 \pm 4,615$ & 0,004
\end{tabular}

Keterangan: P-value $<\alpha, \alpha=0,05$

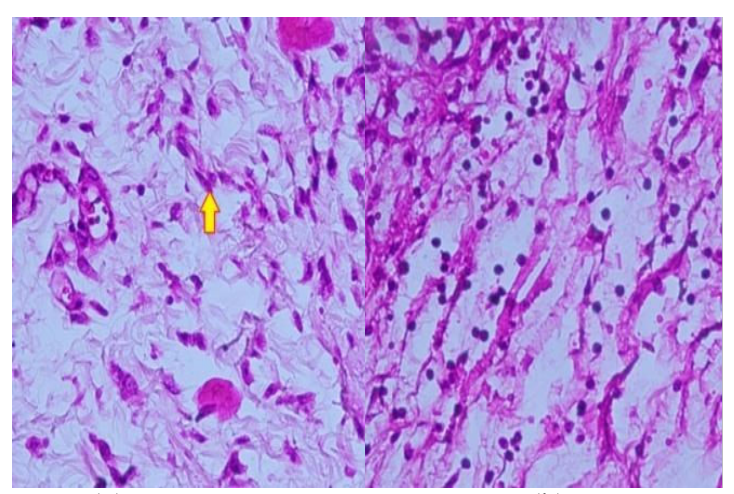

(a)

(b)

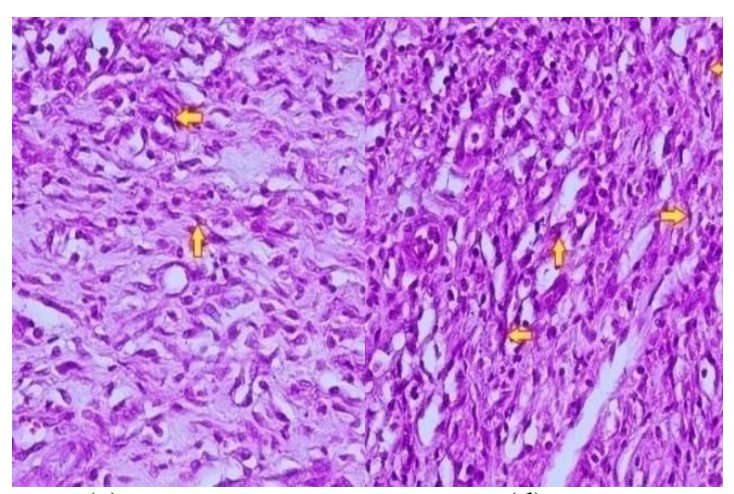

(c)

(d)

Gambar 1.Gambaran Histopatologi fibroblast dengan pewarnaan $\mathrm{HE}$ dan pembesaran 400 kali. a) fibroblast $\mathrm{K} 1$; b) fibroblast $\mathrm{P} 1$; c) fibroblast $\mathrm{K} 2$; fibroblast P2.

\section{HASIL DAN ANALISIS EKSPRESI TNF-A}

Hasil analisis statistik prosentase ekspresi TNF$\alpha$ berdasarkan hasil uji Mann Whitney hewan coba pada kelompok K1, P1, K2, dan P2 dirangkum pada tabel 3 .

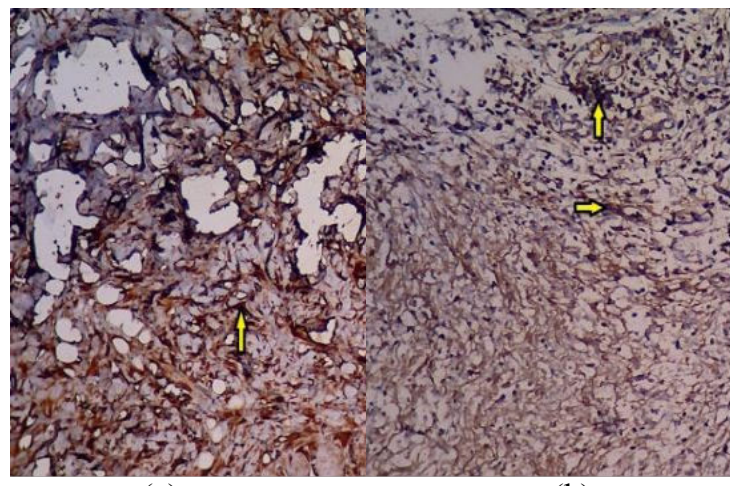

(a)

(b)

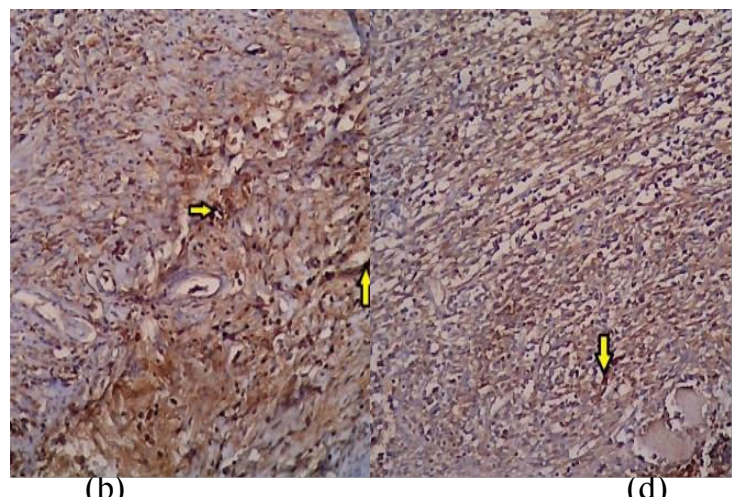

Gambar 2. Interpretasi imuno histokimiaTNF- $\alpha$ pada pembesaran 100 kali. a) K1;b) P1; c) K2; d) P2.

Tabel 2. Hasil analisis interpretasi TNF- $\alpha$ luka bakar tikus Wistar

\begin{tabular}{ccc}
\hline Kelompok & Mean \pm Std & P-value \\
\hline K1 & $55,000 \pm 19,748$ & 0,388 \\
\hline P1 & $43,333 \pm 22,509$ & \\
\hline K2 & $31,667 \pm 19,408$ & \multirow{2}{*}{0,022} \\
\hline P2 & $10,000 \pm 10,954$ & \\
\hline
\end{tabular}

Keterangan:P-value $<\alpha, \alpha=0,05$ 
Berdasarkan table 1 menunjukkan pada hari ke3 kelompok P1 memiliki jumlah fibroblast lebih tinggi dibandingkan kelompok K1. Pada hari ke-10 kelompok P2 memiliki jumlah fibroblast lebih tinggi dibandangkan kelompok K2. Berdasarkan hasil uji Mann Whitney dengan SPSS 16.00 menunjukkan terjadi perbedaan yang signifikan antara K1 dan P1, K2, dan P2 sehingga dapat disimpulkan bahwa pemberian ekstrak kolagen kulit ikan Lele sangkuriang pada luka bakar derajat II tikus Wistar mampu meningkatkan jumlah fibroblast baik pada hari ke-3 dan ke-10 selama masa penyembuhan.

Pemeriksaan mikroskopis dilakukan secara histopatogi dengan membuat preparat dari spesimen luka bakar tikus. Pewarnaan dilakukan dengan menggunakan hematoxylin eosin (HE). Bentuk fibroblast pada pembacaan histopatologi dengan pewarnaan HE pada pembesaran 400x yaitu berbentuk serabut panjang dengan inti sel yang tampak pipih kehitaman. Pada gambar 1 fibroblast ditunjukkan pada penunjuk warna kuning. hasil pembacaan menunjukkan jumlah fibroblast pada perlakuan kelompok P1 lebih tinggi daripada kelompok K1, dan perlakuan kelompok P2 lebih tinggi daripada kelompok K2.

Berdasarkan tabel 2 menunjukkan pada hari ke3 kelompok P1 memiliki prosentase TNF- $\alpha$ lebih rendah dibandingkan kelompok K1. Pada hari ke-10 kelompok P2 memiliki TNF- $\alpha$ lebih rendah dibandingkan kelompok K2. Berdasarkan hasil uji Mann Whitney dengan SPSS 16.00 menunjukkan terjadi perbedaan yang signifikan antara K1dan P1, K2 dan P2, hal ini menunjukkan bahwa pemberian ekstrak kolagen kulit ikan Lele Sangkuriang pada luka bakar derajat II tikus Wistar mampu menurunkan prosentase TNF- $\alpha$ baik pada hari ke-3 maupun hari ke-10 secara signifikan.

\section{KESIMPULAN}

Dari hasil penelitian ini dapat disimpulkan bahwa pemberian ekstrak kolagen kulit ikan Lele Sangkuriang dapat membantu penyembuhan luka bakar derajat II tikus Wistar, dengan menurunkan TNF- $\alpha$ dan meningkatkan jumlah fibroblast.

\section{DAFTAR PUSTAKA}

Boateng, Joshua S. Matthews, Kerr H. Stevebs, Hward N.E. Eccleston, Gillia M. 2008. Wound Healing Dressingsand Drug Delivery Systems: A Review. Journal of Pahramceutical Science, Vol. 97, No. 8, August 2008

Bryan, Nicholas. Ahswin, Helen. Smart, Neil. Bayon, Yves. Wohlert, Stephen. Hunt, John A. 2012. Reactive Oxygen Species (ROS) A Family Fate Deciding Molecules Pivotalin Constructive Inflamation and Wound Healing. European Cells and Material Vol 24. 2012 (pages 249-265)

Dewi, Yulia Ratna Sintia. 2013. Luka Bakar: Konsep Umum dan Investigasi berbasis Klinis Luka Antemortem dan Postmortem. Universitas Udayana

Soni, A. Dwivedi, V. K. Chaudhary, M. Shrivastava, S. M, Naithani, V. 2010. Efficacy of Ampucare: A Novel Herbal Formulation for Burn Wound Healing Versus Other Burn Medicines. Asian Journal of Biological Sciences 3 (1): 18-27, 2010

Eming, Sabine A. Krieg, Thomas. Davidson, Jeffrey M. 2007. Inflammation in Wound Repair: Molecular and Cellular Mechanisms. Journal of Investigative Dermatology (2007), Volume127

Fore, Jane. 2014. Type 1 Collagen and Wound Healing. Tri-State Wound Careand Hyperbaric Center, Clarkston, Washington

Geethalakshmi, R. Sakravarthi, C. Kritika, T. Kirubakaran, M. Arul. Sarada, D. V. L. Evaluation of Antioxidantand Wound Healing Potentials of Sphaeranthus amaranthoides Burm.f. BioMed Research International, Volume 2013, Article ID 607109, 7 pages

Gelse, K. Poschl, E. Aigner, T. 2003. CollagensStructure, Function, and Synthesis. Advanced Drug Delivery, 2003;55:15311546 
Gusasi, Sulandri. 2011. Pengaruh Collagen Wound Dressing terhadap Penyembuhan Luka Kulit Tikus. Departemen/SMF Bedah Plastik Fakultas Kedokteran Universitas Airlangga/ RSUD Dr. Soetomo

Hidayat, Taufiq Sakti Noer. 2013. Peran Topikal Rkstraj Gel Aloe Vera pada Penyembuhan Luka Bakar Derajat Dalam pada Tikus. Karya Akhir, Departemen/SMF Ilmu Bedah Plastik Rekonstruksi dan Estetik, Fakultas Kedokteran/RSUD Dr. Soetomo, Surabaya

Kementrian Kesehatan. 2013. Riset Kesehatan Dasar: Riskesdas 2013. Badan Penelitian dan Pengembangan Kesehatan Kementrian Kesehatan Republik Indonesia

Kordi H, M. K., Ghufron. 2010. Budi Daya Ikan Lele di Kolam Terpal. Lily Publisher: Yogyakarta

Liu, Hai Ying. Li, Ding. Guo, ShiDong. 2006. Studies on Collagen from The Skin of Channel Catfish (Ictalurus punctaus). Food Chemistry, 2007;101:621-625

Liu, Huinan. Webster, Thomas J. 2007. Nanotechnology for The Generation of Hard and Soft Tissue. World Scientific Publishing Co. USA

Polla, Luigi L. Tacchini, Philippe. Neequaye, Alice. Polla, Ada. Polla, Barbara. Pouillot, Anne. 2011. Natural Antioxidants and Their Effectson the Skin. Formulating, Packaging, and Marketing of Natural Cosmetic Products, First Edition. John Wiley \& Sons, Inc.

Sahib, Salih A. S, Al-Kaisy, S. J, Al-Biati, H. A. K. How to decrease the incidence of Eschar Formation during The Use of Topical Povidone- Iodine Ointmentin The Treatment of Burns. Annals of Burn and fire DisastersVol. XIX-n. 1 -March 2006
Saraf, S. Parihar, S. 2007. Burns Management: A Compendium. Journal of Clinical and Diagnostic Research [serial online] 2007 October [cited: 2007 Oct 1]; 5: 426-436

Shoulders, Matthew D. Raines, Ronald T. 2009. Collagen Structure and Stability. Annu. Rev. Biochem. 2009. 78: 929-58

Singh, Prabjeet. Benjakul, Soottawat. Maqsood, Sajid. Kishimura, Hideki. 2010. Isolation and Characterisation of Collagen Extracted from the Skin os Striped Catfish (Pangasionodon hipopthalmus). Food Chemistry, 2011; 124: 97-105

Triyono, Bambang. 2005. Perbedaan Tampilan Kolagen disekitar Luka Insisi pada Tikus Wistar yang diberi Infiltrasi Penghilang Nyeri Levobupivakain dan yang tidak diberi levobupivakain. Tesis, Magister Ilmu Biomedik dan Program Pendidikan Dokter Spesialis I bidang anestesiologi, Universitas Diponegoro

Tsala, David Emery. Amadou, Dawe. Habtemariam, Solomon. 2013. Natural wound healing and bioactive natural products. Phytopharmacology 2013, 4(3), $532-560$

Tuan, Tai-Lan. Nichter, Larry S. 1998. The molecularbasis of keloid and hypertrophic scarformation. Molecular Medicine Today, January 1998. Elsevier Science Ltd.

Turley, Andrew. 2015. Fish skin dressing helps heal wound. Chemistry World, 18 February 2015

Vrabete, Maria. Spulber, Corina. 2011. Oxidative Stress-Implications in Burn Patient Undergo Surgery. University of Medicine and Pharmacy Craiova. 